\title{
Analysis of the Operating Point and Fault Current Contribution of a PEMFC as Distributed Generation (DG)
}

\author{
Dae-Seong Moon*, Gi-Hyeok Kang*, Il-Yop Chung** and Dong-Jun Won ${ }^{\dagger}$
}

\begin{abstract}
Recently, hydrogen energy has been anticipated to change the paradigm of conventional power systems because it can expand sustainable energy utilization and conceptually provide remarkable flexibility to power system operation. Since hydrogen energy can be converted to electric energy through fuel cells, fuel cells are expected to play an important role in the future hydrogen economy. In this paper, a Proton Exchange Membrane Fuel Cell (PEMFC) is modeled as an equivalent circuit and its steady-state characteristics investigated using the model. PEMFCs can be connected to power systems through power conditioning systems, which consist of power electronic circuits, and which are operated as distributed generators. This paper analyzes the effects of the characteristics of the PEMFC internal voltages and investigated the dynamic responses of the PEMFC under fault conditions. The results show that the fault current contribution of the PEMFC is different from those of conventional generators and is closely related to its operating point.
\end{abstract}

Keywords: distributed generation, distribution system, fault, modeling, hydrogen, proton-exchange membrane fuel cell

\section{Introduction}

The oil price crisis in recent years has led to increasing concerns about the severe dependence upon fossil fuels that may deteriorate the local or global economy and energy security. On top of it all, the greenhouse gas emissions of fossil fuels will be a more significant issue in near future. Therefore, the development of sustainable energy sources that can substitute dwindling fossil fuels are now fairly essential issues. Among alternative energy sources, hydrogen energy will be one of the best solutions with regard to availability and environmental impact. Hydrogen can be obtained via electrolysis of water, and when it reacts with oxygen, only pure water is produced rather than environmental pollutants. Therefore, the construction of a hydrogen economy could secure a sustainable energy supply.

The major use of hydrogen in the hydrogen economy would be in fuel cells. A fuel cell is an electrochemical device that directly converts the chemical energy of hydrogen and oxygen into electrical energy, constantly producing electricity and heat by supplying hydrogen and oxygen to an anode and a cathode. Current fuel cell efficiencies range from 40 to 50 percent at full power and 60 percent at a quarter power, with up to 80 percent efficiency reported for combined heat and power applications [1]. Since hydrogen is environmentally clean, fuel cells can provide 20 to 40 percent less carbon quantity than conventional power

$\dagger$ Dept. of Electrical and Electronic Engineering, Inha University, Korea.(djwon@inha.ac.kr)

* Dept. of Electrical and Electronic Engineering, Inha University, Korea. (her_soul@hotmail.com,kakihyu@gmail.com)

** Center for Advanced Power System, Florida State University, Tallahassee, FL, USA. (ilyop.chung@gmail.com)

Received 21 January 2009; Accepted 6 July 2009 plants [2].

Among various types of fuel cells, Proton Exchange Membrane Fuel Cells (PEMFCs) have some strengths, such as low temperature operation and high output density that can reduce the size of the whole system [3-4]. Therefore, PEMFCs are expected to become widespread as household energy supplies. In fact, more than 100 household fuel cells of about $1 \mathrm{~kW}$ have been practically installed since 2006 [2].

Most recent studies have focused on the steady-state analysis of PEMFCs. Meanwhile, the interconnection of PEMFCs to power systems has drawn relatively little attention from researchers. One previous work presented the power control of PEMFCs operated as distributed generators (DG) and discussed their safe operating range during faults [5]. However, the reference [5] did not pay much attention to the effect of each operating point of the PEMFC on the fault contribution. This paper focuses on the fault current contribution of PEMFCs by analyzing their operating points. In order to find the detailed relationship between fault contribution and operating points, this paper models the PFMFC as an equivalent electric circuit and analyzes the steady-state and dynamic characteristics of the PFMFC. Multiple PEMFCs were then integrated to construct a $2 \mathrm{MW}$ fuel cell system, which is connected to a power system. The PEMFC output characteristics and fault performances were then discussed in the context of a DG system.

\section{PEMFC Model}

A PEMFC utilizes hydrogen as fuel over a platinum catalyst to produce electrochemical energy and the byproduct 


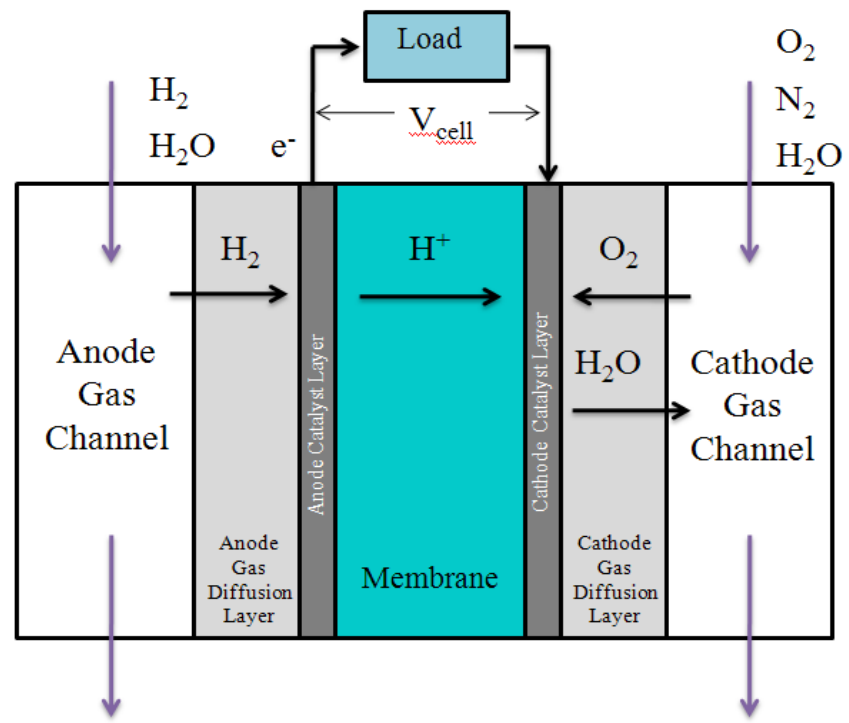

Fig. 1. Schematics of PEMFC chemical reaction

is pure water. Fig. 1 shows the PEMFC energy conversion process. The charge carrier is the hydrogen ion (proton). At the anode, a hydrogen molecule is split into hydrogen ions and electrons. The hydrogen ions permeate the electrolyte to the cathode while the electrons flow through an external circuit and produce electric power. Oxygen in the air is supplied to the cathode and combines with the electrons and the hydrogen ions to produce water. The reversible voltage of the cell is the potential of the cell obtained in an open circuit thermodynamic balance (without load) [6]. [6-7]:

The fuel cell output voltage can be expressed as follows

$$
V_{\text {out }}=N_{\text {cell }} \cdot V_{\text {cell }}=V_{\text {nernst }}-V_{\text {act }}-V_{\text {ohm }}-V_{\text {con }}
$$

Where,

$\begin{array}{lll}V_{\text {nernst }} & : & \text { Nernst voltage } \\ V_{\text {out }} & : & \text { Output voltage of PEMFC stack } \\ N_{\text {cell }} & : & \text { Number of fuel cell } \\ V_{\text {cell }} & : & \text { Output voltage of PEMFC } \\ V_{\text {act }} & : & \text { Activation loss (in volts) } \\ V_{\text {ohm }} & : & \text { Ohmic loss (in volts) } \\ V_{c o n} & : & \text { Concentration loss (in volts) }\end{array}$

\section{1) Activation Loss}

Activation polarization occurs when the rate of the electrochemical reaction at the electrode surface is controlled by sluggish electrode kinetics. The Tafel equation can be used to calculate the activation voltage loss in a PEMFC [7].

\section{2) Ohmic Loss}

Ohmic losses result from the resistance to the flow of ions in the electrolyte and the resistance to the flow of electrons through the electrode materials. This resistance is dependent on cell temperature.

\section{3) Concentration Loss}

As the reactant is consumed at the electrode during the electrochemical reaction, there is a loss of potential due to mass diffusion from the flow channels to the reaction sites.

\section{4) Double-Layer Charging Effect}

A double layer charging effect arises due to the difference of electric charge at the surfaces of the electrode in the fuel cell. This phenomenon causes a first order time delay when the stack current or voltage changes, similar to the performance of an electric capacitor. This delay affects the activation and concentration losses. The ohmic loss has no effect because it has a linear form, which makes the voltage drop immediately in proportion with the stack current.

\section{Performances of a stand-alone PEMFC system}

In this section, the PEMFC output voltage and power are analyzed when the PEMFC is connected to a resistive load. The steady state voltage for one stack $($ Ncell $=48)$ versus the cell current density was obtained based on Eq. (1). Fig. 2 shows the V-I characteristic of the PEMFC stack during steady state [5], [7-9]. The losses are dominant in different conditions: the activation loss, the concentration loss, and the ohmic loss are dominant at light loading condition and heavy loading condition and in the middle of the curve in the PEMFC operating point, respectively.

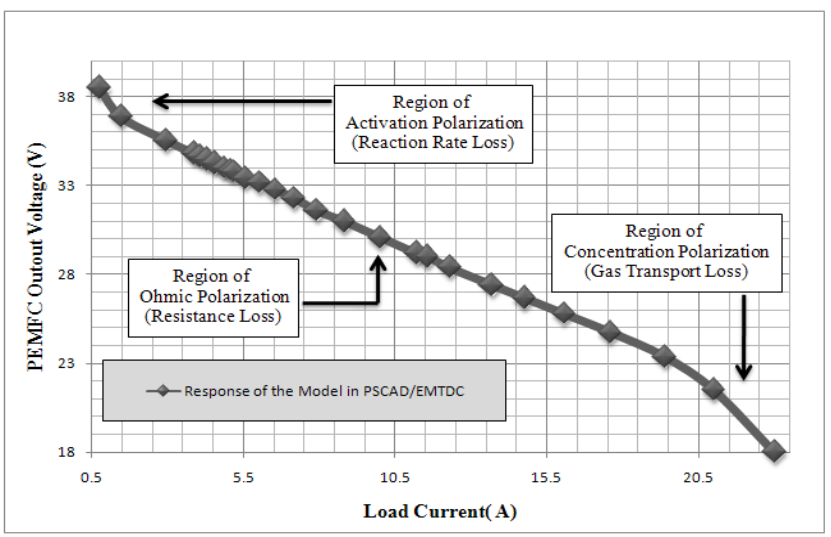

Fig. 2. V-I characteristics of the PEMFC (1Stack)

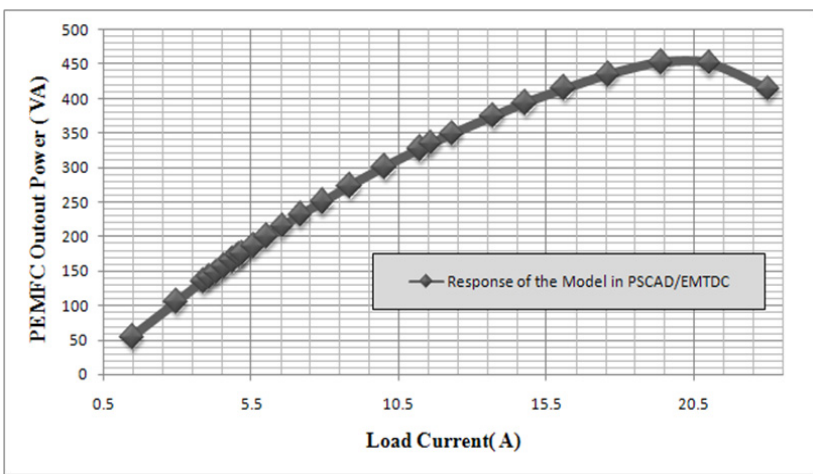

Fig. 3. P-I characteristics of the PEMFC (1Stack) 
Fig. 3 shows the P-I characteristics of the PEMFC during steady state. Maximum power occurs at approximately 21 to $22 \mathrm{~V}$, and relatively high current. Beyond this, the PEMFC goes into the concentration zone, where the PEMFC output power will be decreased with increasing load current due to a sharp decrease in its terminal voltage.

Table 1 shows that the operating point is divided into three parts: first, in the activation region in the V-I curve, the stack output voltage is about $39 \mathrm{~V}$ due to activation loss only; second, in the ohmic region, the stack output voltage is decreased to about $32 \mathrm{~V}$ due to ohmic loss coupled with activation loss; finally, in the concentration region, the stack output voltage is significantly decreased to about $23 \mathrm{~V}$ due to concentration loss in combination with both activation and ohmic losses. Therefore, the stack output voltage is closely affected by activation, concentration, and ohmic losses.

In the developed model, 48 fuel cells were combined to construct a stack. The fuel cell system consists of 160 stacks connected in series and 32 stacks connected in parallel. Due to the series connection of cells in a stack, the total number of series stacks was calculated as

$$
N_{\text {Series,stack }}=V_{\text {system }} / V_{\text {stack }}=4800 / 30=160
$$

Where Vsystem is the external voltage of the PEMFC system for 160 stacks and $V$ stack is the internal voltage of the 48 fuel cell PEMFC stack.

The 32 stacks are connected in parallel. Therefore, the total number of parallel stacks was calculated as

$$
N_{\text {Parallel,stack }}=I_{\text {system }} / I_{\text {stack }}=480 / 15=32
$$

Where Isystem is the external current of the 160 stack PEMFC system and Istack is the internal current of the 48 fuel cell PEMFC stack. As shown in Figs. 4 and 5, the PEMFC system was operated around the point where its current (Isystem) was $480 \mathrm{~A}$ and its output voltage Vsystem was about $4.8 \mathrm{kV}$. As a result, each fuel cell array of $160 \mathrm{x}$ 32 stacks had a power rating of $2.3 \mathrm{MW}$. Table 2 lists the specifications for PEMFC scaling.

Table 1. Voltage drops at different operating points (1 Stack)

\begin{tabular}{lccc}
\hline Voltage $(\mathrm{V})$ & $\begin{array}{c}\text { Activation } \\
\text { Region }\end{array}$ & $\begin{array}{c}\text { Ohmic } \\
\text { Region }\end{array}$ & $\begin{array}{c}\text { Concentration } \\
\text { Region }\end{array}$ \\
\hline Internal & $58.90 \mathrm{~V}$ & $58.50 \mathrm{~V}$ & $58.00 \mathrm{~V}$ \\
Ohmic & $0.00 \mathrm{~V}$ & $4.59 \mathrm{~V}$ & $7.00 \mathrm{~V}$ \\
Concentration & $0.00 \mathrm{~V}$ & $1.68 \mathrm{~V}$ & $5.00 \mathrm{~V}$ \\
Activation & $19.20 \mathrm{~V}$ & $23.92 \mathrm{~V}$ & $23.95 \mathrm{~V}$ \\
Stack output voltage & $39.00 \mathrm{~V}$ & $26.82 \mathrm{~V}$ & $23.00 \mathrm{~V}$ \\
\hline
\end{tabular}

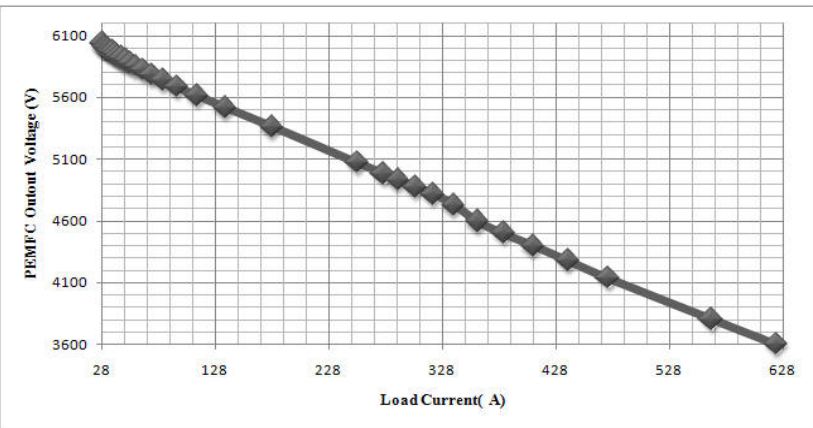

Fig. 4. V-I characteristics of PEMFC system (160 stack)

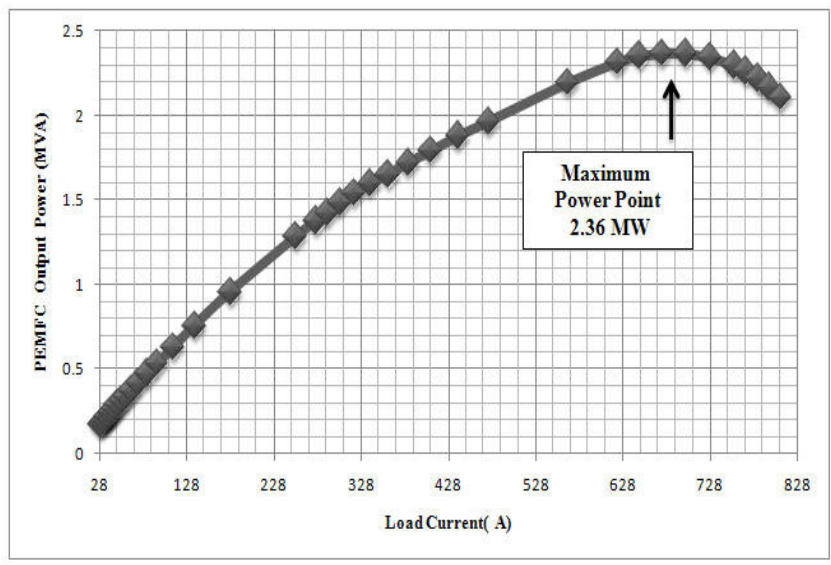

Fig. 5. P-I characteristics of PEMFC system (160 stack)

Table 2. Ratings of the PEMFC system

\begin{tabular}{cc}
\hline Description & Value \\
\hline Number of serial stacks & 160 \\
Number of parallel stacks & 32 \\
Region of operating voltage & $3.6 \mathrm{kV} \sim 6.1 \mathrm{kV}$ \\
Region of operating current & $28 \mathrm{~A} \sim 628 \mathrm{~A}$ \\
\hline
\end{tabular}

\section{Performances of the PEMFC as a Distributed Generation System}

The system consists of PEMFCs connected between Power Grid I and Power Grid II. The PEMFC modeled using PSCAD/EMTDC is shown in Fig. 6. The power conditioning system, which connects the PEMFC to the grid, is made of a DC/DC booster converter, a DC/AC PWM inverter, a harmonic filter, and a transformer. $\mathrm{P}_{\mathrm{PEMFC}, \mathrm{m}}$ and $\mathrm{Q}_{\mathrm{PEMFC}, \mathrm{m}}$ represent the active and reactive power generated by the PEMFC. The power flowed from Power Grid I to Power Grid II with a 35-degree phase shift. The PEMFC connected between Power Grid I and II supplies regulating power to the main feeder by inverter operation.

The output active $\left(\mathrm{P}_{\mathrm{PEMFC}, \mathrm{m}}\right)$ and reactive $\left(\mathrm{Q}_{\mathrm{PEMFC}, \mathrm{m}}\right)$ power of the PEMFC system are measured and compared with the reference active ( $\left.\mathrm{P}_{\mathrm{PEMFC}, \text { ref }}\right)$ and reactive (QPEMFC,ref) power. As shown in Fig. 7, a PI controller in the inverter system is used for active and reactive power control [10]. The power factor of the PEMFC is decided by a set of reference reactive power values. In this model, $\mathrm{P}_{\text {PEMFC, ref }}$ and $\mathrm{Q}_{\text {PEMFC,ref }}$ were 1.9 MW and 0.5 MVAr (the fuel cell output voltage was based on $4.8 \mathrm{kV}$ ). As a result, the power factor was 0.97 .

As shown in Fig. 8, $P_{\text {PEMFC,ref }}$ and QPEMFC,ref increased suddenly to $2.3 \mathrm{MW}$ and $0.6 \mathrm{MVAr}$, respectively, at $\mathrm{t}=5.0 \mathrm{~s}$ for $5.0 \mathrm{~s} \leq \mathrm{t}<8.0 \mathrm{~s}$. The output active $\left(\mathrm{P}_{\mathrm{PEMFC}} \mathrm{m}\right)$ and reactive $\left(\mathrm{Q}_{\mathrm{PEMFC}}, \mathrm{m}\right)$ power in the PEMFC system can be instantaneously controlled according to the $\mathrm{P}_{\mathrm{PEMFC}} \mathrm{m}$ and $\mathrm{Q}_{\mathrm{PEMFC}, \mathrm{ref}}$ by PQ control of the DC/AC Inverter. 


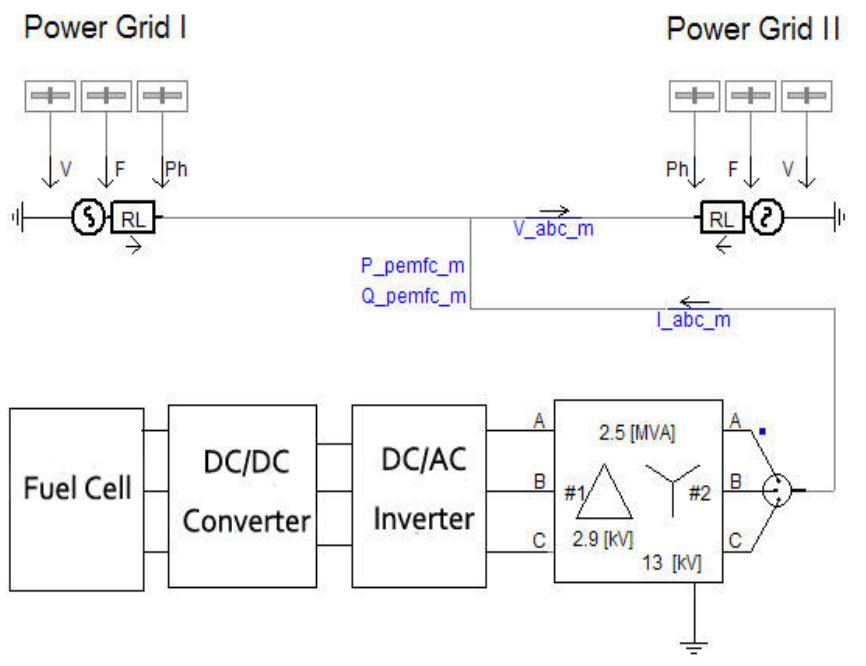

Fig. 6. The PEMFC system connected to power system as a DG

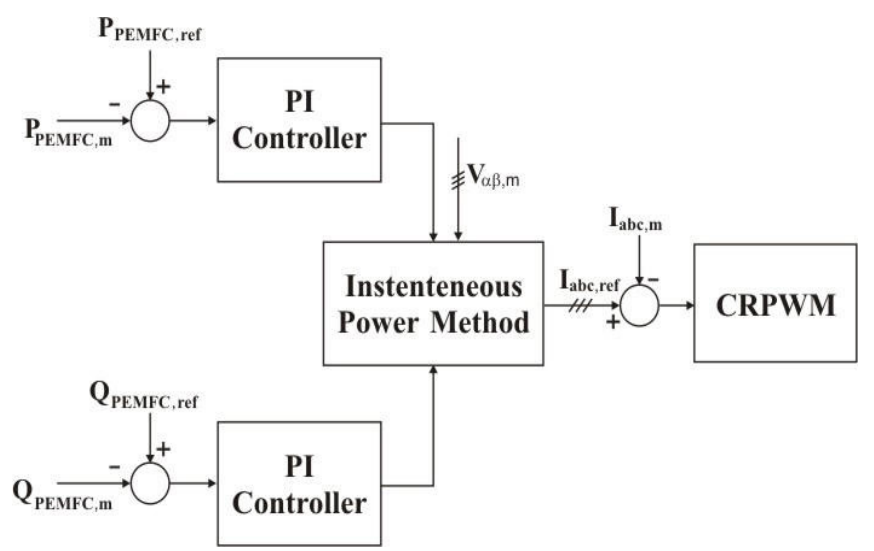

Fig. 7. PQ control system for the PEMF

As shown in Fig. 9, the DC input voltage decreases and the DC input current increases according to the P-I characteristics of the PEMFC system. However, the output voltage is maintained within the control range by operation of the DC/DC booster converter [11]. Table 3 shows the fuel cell, DC/DC converter, and DC/AC inverter output voltage and current. The operating point in the PEMFC system can be decided by $\mathrm{P}_{\mathrm{PEMFC}}$,ref of PQ control and the inverter input voltage can be kept constant by DC/DC converter operation.

Table 3. Magnitude of fault current

\begin{tabular}{cccc}
\hline & Steady-State (kA) & Event-1 (kA) & Event-2 (kA) \\
\hline $\mathrm{I}_{1}$ & 1.08 & 1.71 & 2.69 \\
$\mathrm{I}_{2}$ & 1.13 & 1.39 & 2.72 \\
$\mathrm{I}_{\text {PEMFC }}$ & 0.18 & 0.34 & Unstable \\
$\mathrm{I}_{\mathrm{F}}$ & 0.00 & 3.30 & 5.40 \\
$\mathrm{~V}_{\text {load }}$ & 1.00 & 0.60 & 0.25 \\
\hline
\end{tabular}

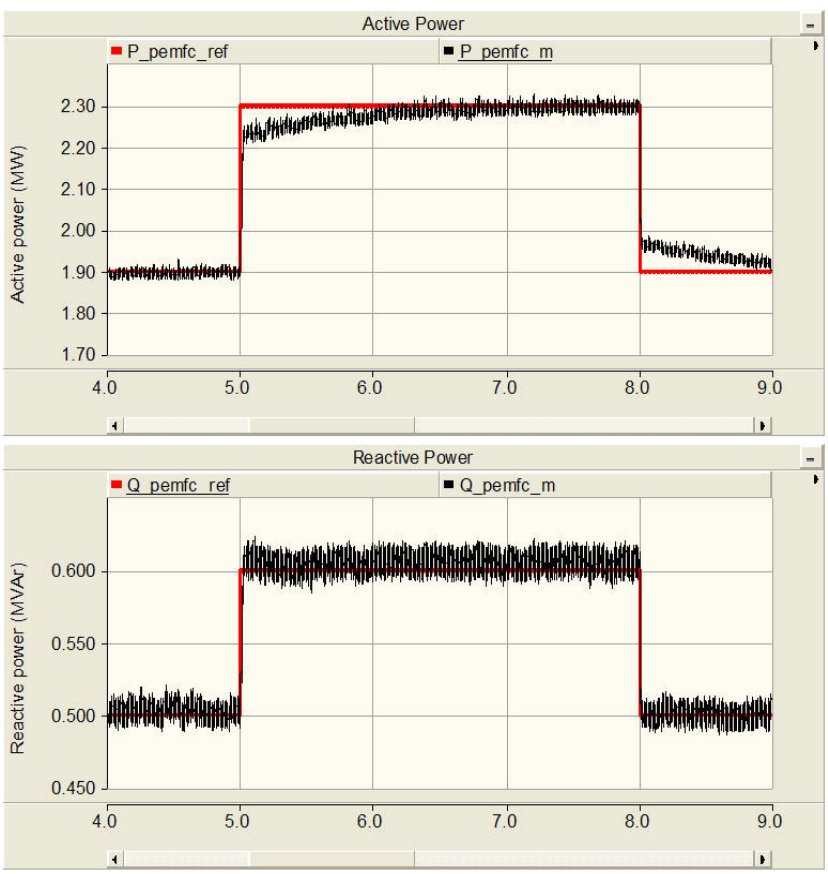

Fig. 8. Step response of the PEMFC system active and reactive power in PQ control mode

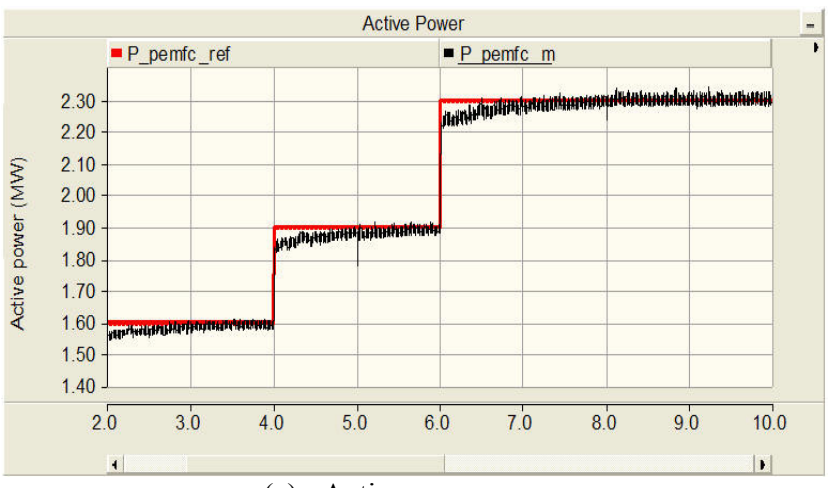

(a) Active power response

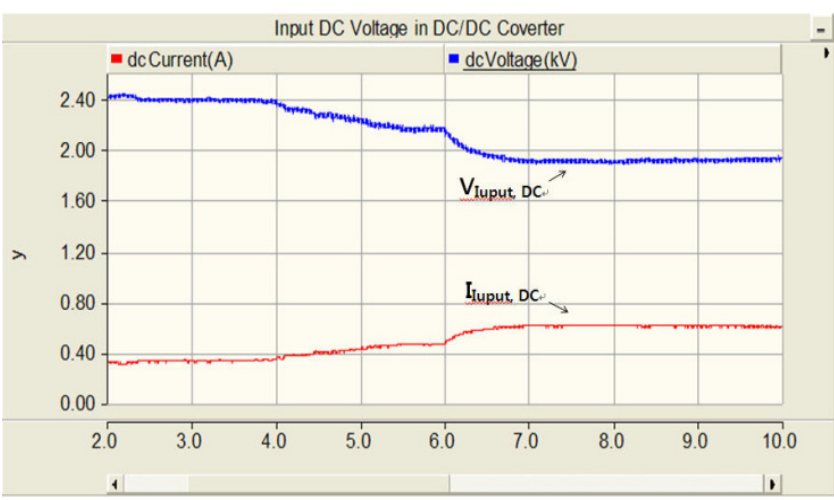

(b) PEMFC voltage and current

Fig. 9. Step response of the PEMFC system active Power

Fig. 10 shows that the operating points of the PEMFC system change according to $\mathrm{P}_{\text {PEMFC,ref }}$ (the fuel cell output voltage was based on $4.8 \mathrm{kV}$ ). $\mathrm{P}_{\text {PEMFC,ref }}$ was changed to 1.6 MW, 1.9 MW, and 2.3 MW, progressively. 


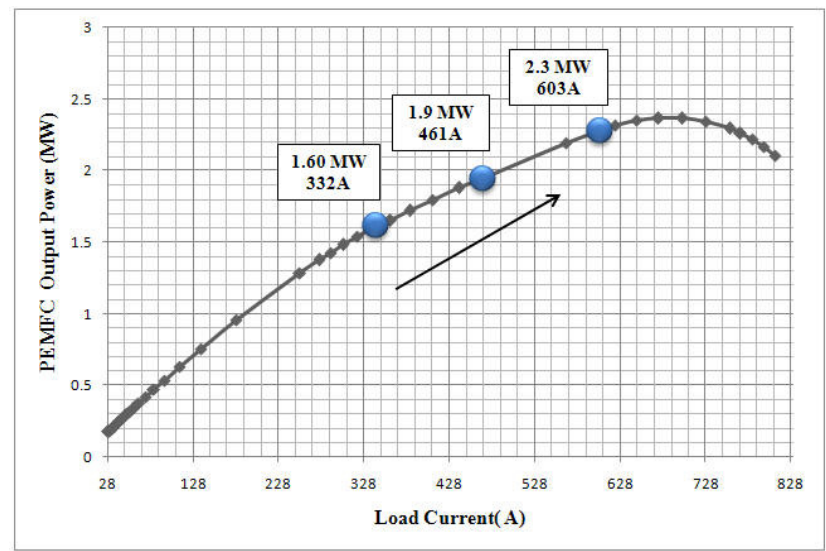

Fig. 10. Change of operating point in P-I characteristics

\section{Fault Current Contribution of a PEMFC System}

For the case study, 2 different fault events are applied to the test system. The fault location and the current notations are depicted in Fig. 11. Two different fault events, with fault resistances of $2.0 \Omega$ and $0.5 \Omega$ were simulated whereas the fault locations are the same. Figs. 12 and 13 show the simulation results of a 3-phase short-circuit test applied between $5.0 \mathrm{~s} \leq \mathrm{t}<6.0 \mathrm{~s}$ and $7.0 \mathrm{~s} \leq \mathrm{t}<8.0$. Table 3 shows the fault current magnitude for each fault event.

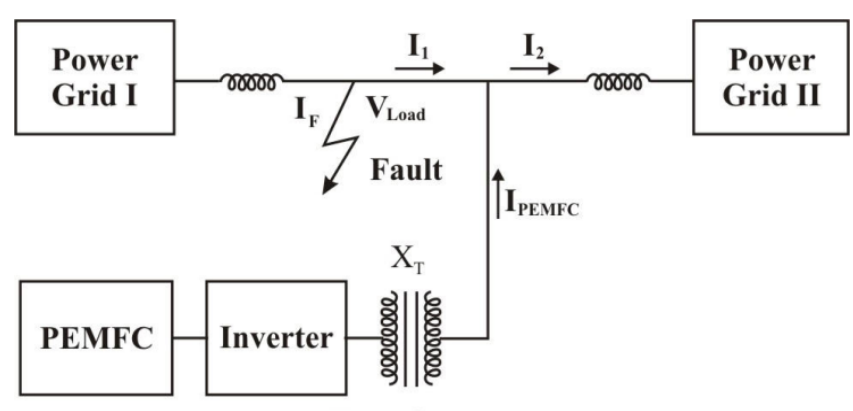

Transformer

Fig. 11. Fault location and current notations in the test power system with a PEMFC

In cases 1 and 2, as shown in Figs. 12 and 13, respectively, three lines to the ground fault in the system are presented nearby Power Grid I. Voltage sag occurs and a large fault current flows from Power Grid I, Power Grid II, and the PEMFC system. However, case 1 and case 2 are different in several ways.

Firstly, when the fault resistance is $2 \Omega$, for $5.0 \mathrm{~s} \leq \mathrm{t}<$ $6.0 \mathrm{~s}$, the output current of the PEMFC system is increased to $342 \mathrm{~A}$ due to the fault event and flows to the main grid feeder, as shown in Fig. 12(c). QPEMFC,m is increased slightly due to the fault current, as shown in Fig. 13(b). However, $\mathrm{P}_{\mathrm{PEMFC}}$ of of the PEMFC system was almost unchanged due to $\mathrm{P}$ control operation at the inverter, as shown in Fig. 13(a). At this time, the fault current (I1) from power grid I was increased from $1.09 \mathrm{kA}$ to $1.71 \mathrm{kA}$ and the fault current (I2) from power grid II was increased from $1.14 \mathrm{kA}$ to $1.40 \mathrm{kA}$, because the fault current $\left(\mathrm{I}_{\mathrm{f}}\right)$ of
$3.30 \mathrm{kA}$ was supplied from power grid I, power grid II, and the PEMFC. Secondly, at $\mathrm{t}=7$ for $7.0 \mathrm{~s} \leq \mathrm{t}<8.0 \mathrm{~s}$, when the fault resistance was $0.5 \Omega$, the PWM inverter control failed. Figs. 12(a) and (b) show that $\mathrm{I}_{\text {load1 }}$ and $\mathrm{I}_{\text {load2 }}$ were significantly increased. For these reasons, the PEMFC system became unstable, and $\mathrm{P}_{\mathrm{PEMFC}, \mathrm{m}}$ and $\mathrm{Q}_{\mathrm{PEMFC}}$, did not follow $P_{\text {PEMFC,ref }}$ and $Q_{\text {PEMFC,ref }}$ as shown in Fig. 13.

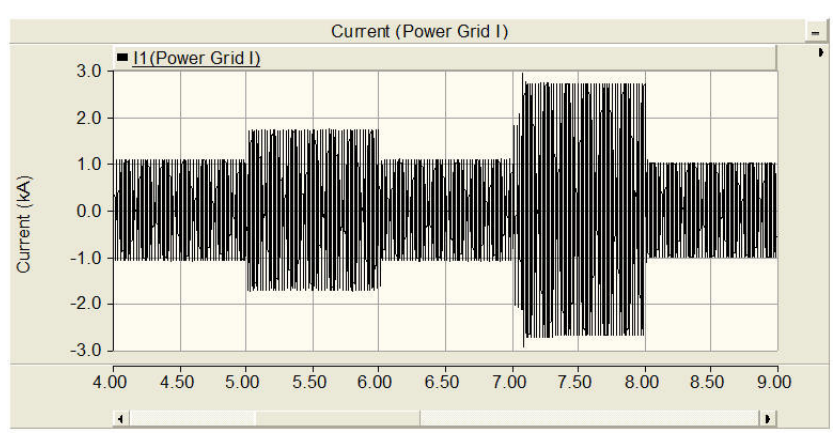

(a) Fault current from power grid I

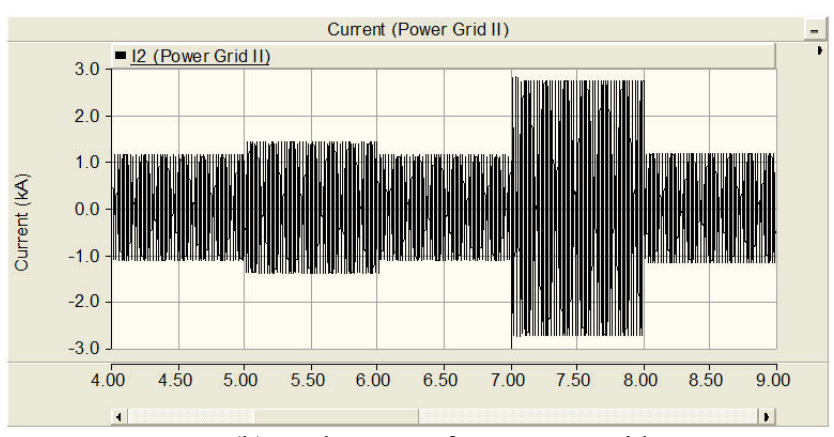

(b) Fault current from power grid II

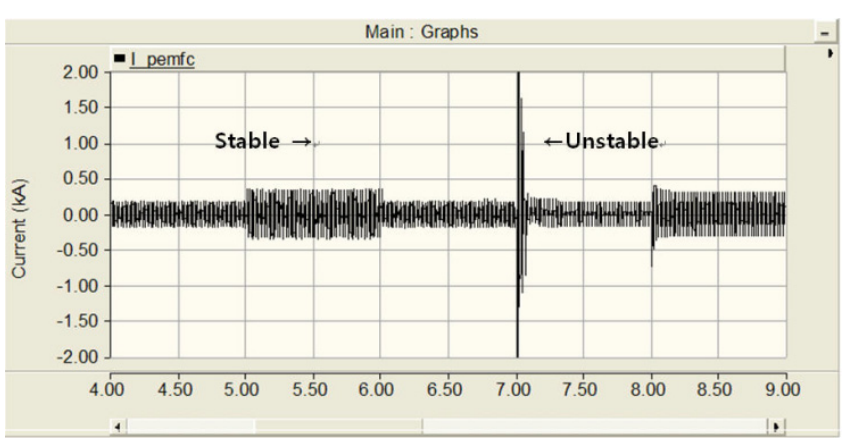

(c) Fault current from the PEMFC system

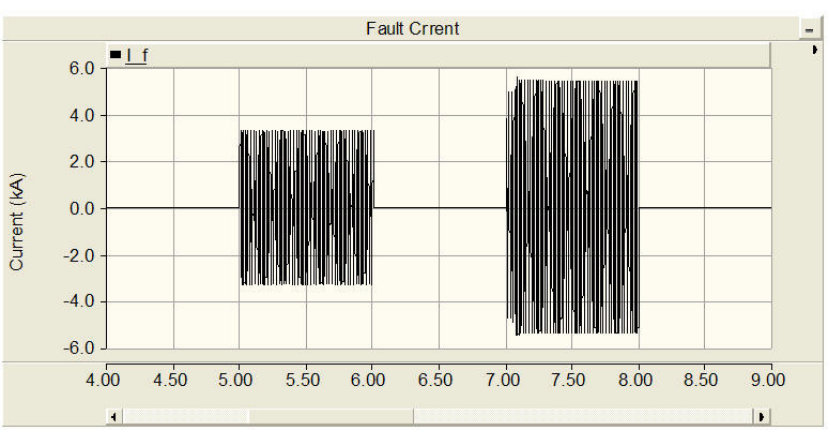

(d) Fault current at fault location

Fig. 12. Fault currents with two different faults 


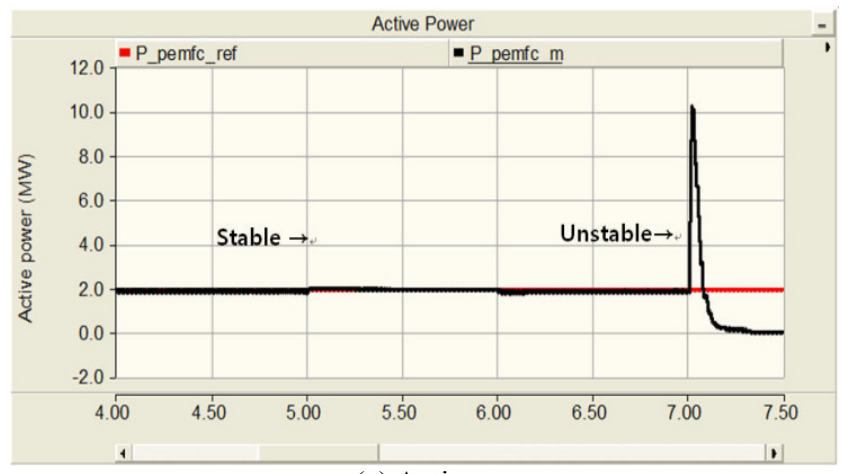

(a) Active power

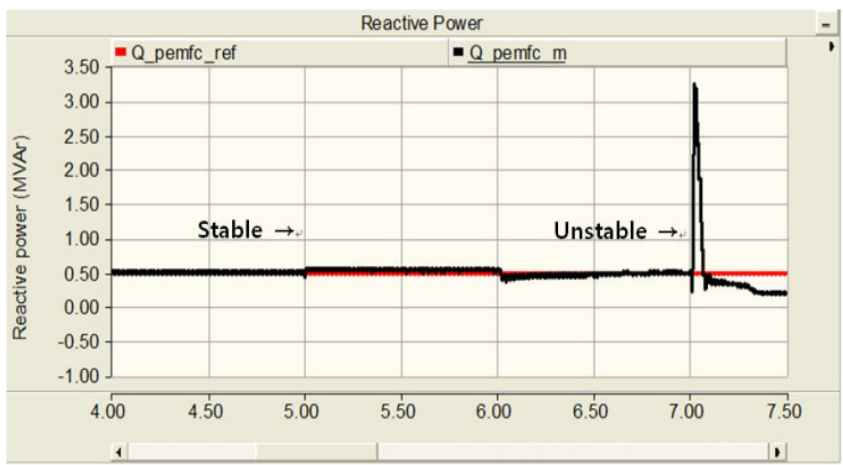

(b) Reactive power

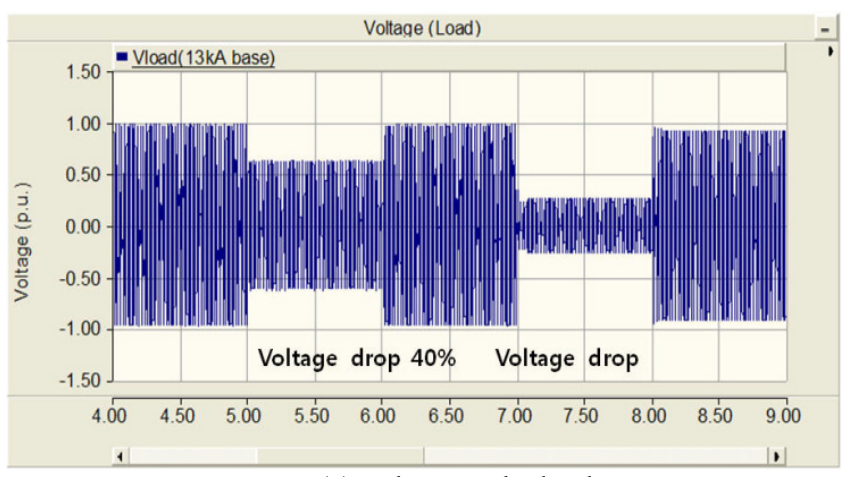

(c) Voltage at the load

Fig. 13. Active and reactive power of the PEMFC system, voltage at the load during fault event

Fig. 14 shows the operating characteristics of the PEMFC system before and after the fault event. At a fault resistance of $2 \Omega$, the DC voltage and current of the PEMFC were 4.4 $\mathrm{kV}$ and $461 \mathrm{~A}$, respectively, within $\pm 5 \%$. The active power of the PEMFC system was controlled at roughly $2.3 \mathrm{MW}$. The operating point was almost unchanged due to PQ control. However, at a fault resistance of $0.5 \Omega$, the output current of the PEMFC system was increased significantly beyond the operating region. The operating point was changed due to increasing DC current and decreasing DC voltage, as shown in Figs. 14-15. (The fault current of the PEMFC exceeded 828 A). Therefore, the PEMFC system became unstable and uncontrollable. So if the operation point is near the maximum power point, the PEMFC system couldn't flexibly deal with a fault as the margin of a stable current is low.

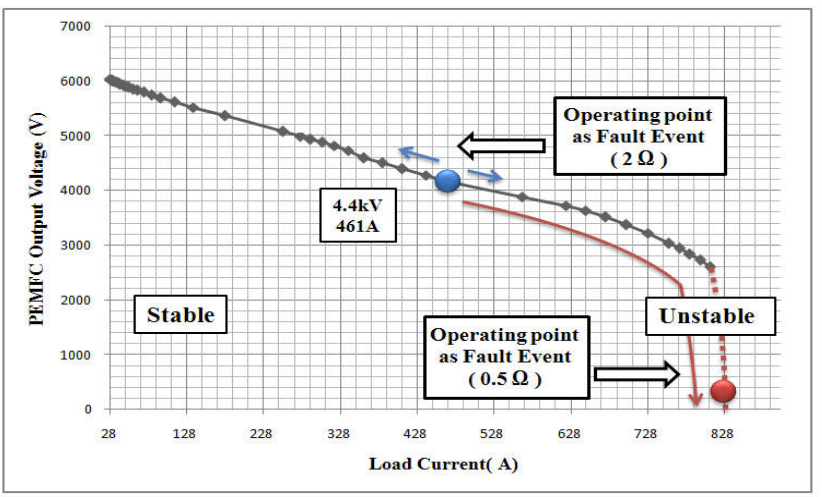

(a) V-I characteristics at fault event

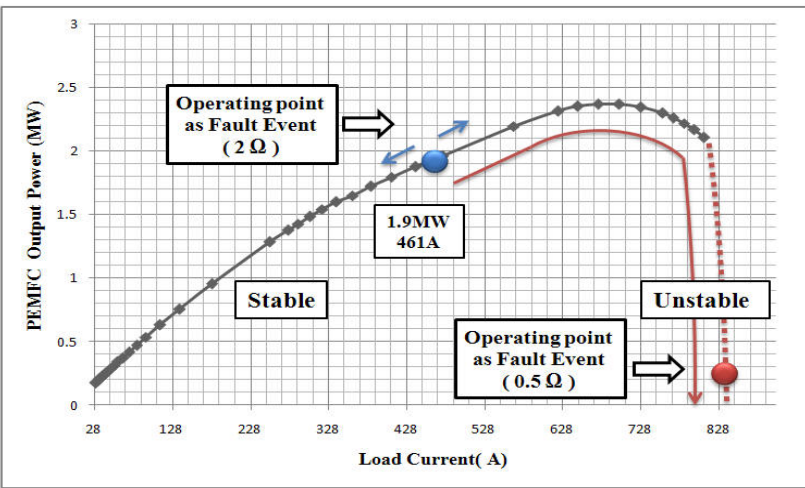

(b) P-I characteristics at fault event

Fig. 14. Operating points of the PEMFC at steady state and during a fault even

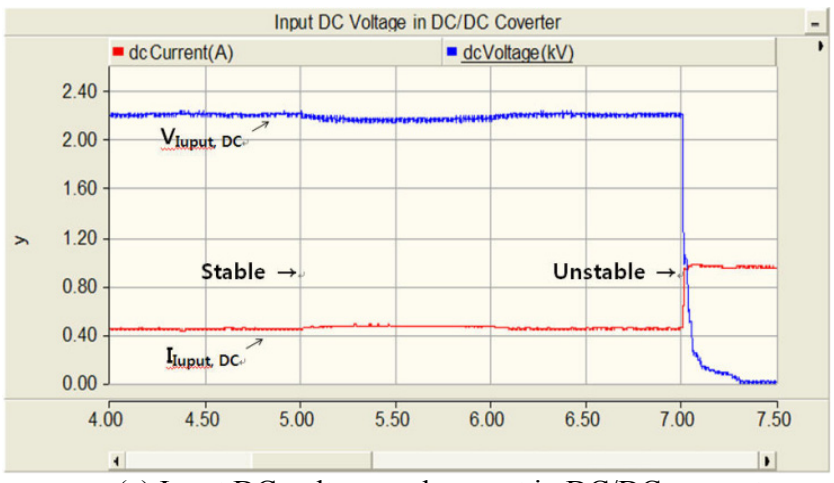

(a) Input DC voltage and current in DC/DC converter

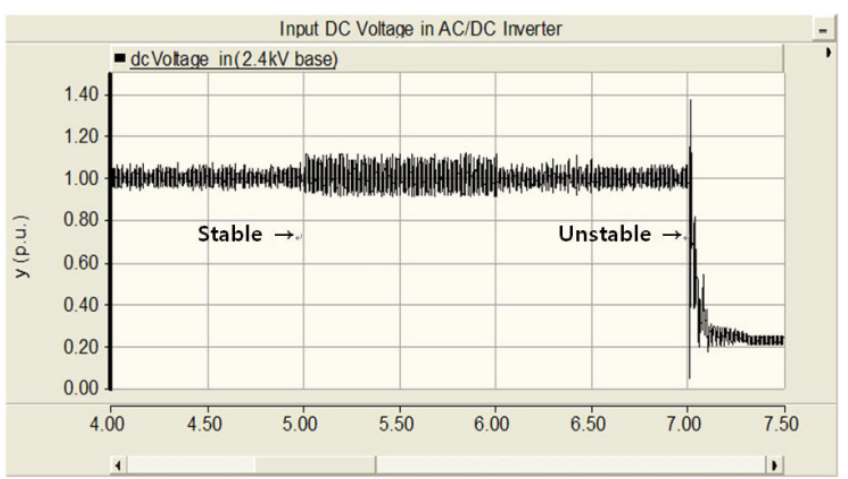

(b) put DC voltage in DC/DC converter

Fig. 15. DC voltage and current of PEMFC system 


\section{Conclusion}

This paper has presented the internal dynamics of PEMFCs and their dynamic responses during faults. The simulation of PEMFC operation was performed using PSCAD/EMTDC. The V-I and P-I characteristics of the PEMFC system have been presented and the fault current related to fault events was analyzed. The results show that the PEMFC system can be added to a power generation system and provide active and reactive power in a stable manner through PQ control within the operating region. When a large fault that cannot be managed by the PEMFC occurs in the power system, the PEMFC system becomes unstable and uncontrollable. And the PEMFC system operated near the maximum power couldn't flexibly deal with a fault.

\section{Acknowledgement}

This work is the outcome of a Manpower Development Program for Energy and Resources supported by the Ministry of Knowledge and Economy (MKE)

\section{References}

[1] National Hydrogen Energy Roadmap, United States Department of Energy, Nov. 2002.

[2] Korea Energy Management Corporation [online]. Available : http://www.energy.or.kr/

[3] J. Larminie and A. Dicks, Fuel Cell Systems Explained, New York: Wiley, 2001.

[4] (2001, May) Collecting the history of fuel cells. Smithsonian national museum of American history. [Online]. Available: http://americanhistory.si.edu/ csr/ fuelcells.

[5] C. Wang, M. H. Nehrir, and H. Gao, "Control of PEM Fuel Cell Distributed Generation Systems," IEEE Trans. Energy Conversion, Vol. 21, Issue 2, pp. 586595, June. 2006.

[6] Fuel Cell Handbook, 5th ed., EG\&G Services Parsons Inc., U.S. Department of Energy, 2000.

[7] C. Wang, M. H. Nehrir, and S. R. Shaw, "Dynamic models and model validation for PEM fuel cells using electrical circuits", IEEE Trans. Energy Conversion, Vol. 20, No. 2, pp. 442-451, Jun. 2005.

[8] M. Tanrioven, and M. S. Alam, "Modeling, Control, and Power Quality Evaluation of a PEM Fuel CellBased Power Supply System for Residential Use," IEEE International Conference on Control and Automation, Vol. 43, No. 6, pp. 1499-1506, Nov.-Dec. 2007.

[9] M. Tanrioven, and M. S. Alam, "Modeling, Control, and Power Quality Evaluation of a PEM Fuel CellBased Power Supply System for Residential Use," IEEE Transactions on Industry Applications, Vol. 42, No. 6, pp. 1582-1589, Nov-Dec. 2006.

[10] B. Delfino and F. Fornari, "Modeling and Control of an Integrated Fuel Cell-Wind Turbine System", IEEE Bologna Power Tech Conference, Vol. 2, 23th-26th, June. 2003.

[11] Dong-Jing Lee and Li Wang, "Dynamic and SteadyState Performance of PEM Fuel Cells under Various Loading Conditions", IEEE Power Engineering Society General Meeting, pp. 1-8, June. 2007.

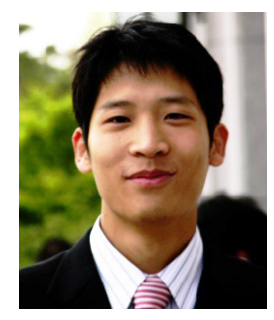

uted generation.

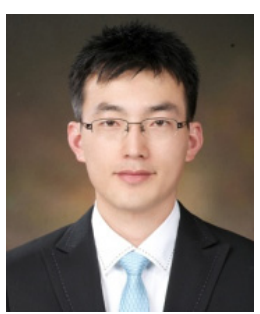

Gi-Hyeok Kang was born in Korea on July 26, 1981. Currently, he is a graduate student in the School of Electrical Engineering, at INHA University, Incheon. His research interests include fuel cells, distributed generation, and microgrids.

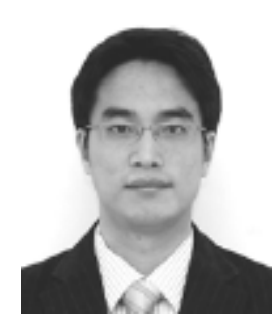

Il-Yop Chung received his B.S., M.S., and $\mathrm{Ph} . \mathrm{D}$. degrees in Electrical Engineering from Seoul National University, Seoul, Korea in 1999, 200, and 2005 , respectively. Currently he is an Assistant Scholar Scientist with the Center for Advanced Power Systems (CAPS) at Florida State University, Tallahassee, FL, USA. His research interests are power quality, distributed energy resources, and microgrids.

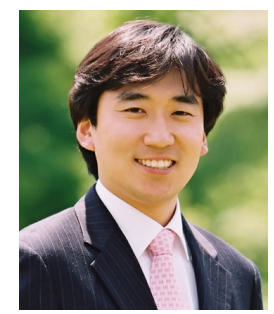

Dong-Jun Won (M’ 2005) was born in Korea, on January 1, 1975. He received his B.S, M.S., and Ph.D. degrees in electrical engineering from Seoul National University, Seoul, Korea in 1998, 2000, and 2004, respectively. He was a Postdoctoral Fellow with the APT Center, University of Washington, Seattle. Currently, he is an assistant professor with the School of Electrical Engineering at INHA University, Incheon, Korea. His research interests include power quality, distributed generation, renewable energy, and hydrogen economy. 